\author{
Radosław Fellner \\ mgr \\ Centrum Kształcenia Kadr Lotnictwa Cywilnego Europy Środkowo-Wschodniej \\ Politechniki Śląskiej \\ rfellner@wp.pl
}

DOI: $10.35117 /$ A_ENG_17_12_04

\title{
Unmanned aerial vehicles as a tool to support aerodrome services
}

\begin{abstract}
The aim of this paper is to show the possibility of using UAV by airport managers. With a few exceptions, there are no studies on this issue. This article is an attempt to fill these research gap. This article is based on the results of studies of the Department of Air Technologies of the Silesian University of Technology, Civil Aviation Personnel Education Centre of Central and Eastern Europe Silesian University of Technology, RPAS TEAM functioning within the Centre. It has been reported that the airport's UAV may serve such services as: Airport Protection Service (patrolling and protecting area near aerodrome), Rescue and Fire Fighting Services (accident area monitoring), airport maintenance and infrastructure services (monitoring and inspection of buildings, pavements, roads, installations), operational departments or duty departments (better visualization of the operational situation).
\end{abstract}

Keywords: Unmanned aerial vehicles; Aerodrome; Airport; Safety

\section{Introduction}

The growing number of Unmanned Aerial Vehicles (UAVs) and operations they perform whether for civilians or army - has created the need to develop even more precise rules related to the certification of these devices, flight rules, licensing of operating personnel and collection data. It also caused the use of these devices in more and more new areas of transport. With the popularisation of the so-called drones, also increased the risk of incidents, including incidents and aviation accidents near airports. Only in 2016. The Civil Aviation Office recorded 20 events with the participation of UAV [5], of which 6 in CTR: EPRW, EPLL, EPLB, EPBY, EPWA, EPKK. Until November 2017, there was only one incident involving UAV, but not within the CTR. For comparison, the US Air Safety Authority reported in 2016 that it received over 100 complaints every month from pilots and airport representatives on drones that were too close to an airport or aircraft [12].

It should be remembered that ensuring the safety of aviation operations is one of the responsibilities of the airport managing body. Unauthorized aircraft used in the wrong way may endanger the execution of takeoffs and landings. On the other hand, the cognitive interest seems to be the proposal to use them in a proper and thoughtful way to increase the safety of these operations. In this context, BSPs can complement the airport security management system and the airport service support tool. Airport departments should be understood as airport personnel or organizational units set up by the airport manager whose tasks relate to such operations at the airport as the take-off or landing of an aircraft. The start of the operation is considered to be the starting of the engine or engines, and the shutdown of the engine or engines [7] as the end. After all, it is the airport manager who is obliged to use the airport in accordance with its intended purpose, operate the airport in a way that ensures continuity of air traffic and flight safety, service efficiency of airport users and maintain the airport and its elements in a condition corresponding to technical conditions [11]. This paper aims to show the possibility of using UAV precisely by airport managers. With few 
exceptions [2], there is a lack of research on these issues. This article is an attempt to fill even the minimum research gap found above. The article is based on the results of research conducted by the Department of Aeronautical Technologies at the Silesian University of Technology, Center for Civil Aviation Cadre Education of Central and Eastern Europe, Silesian University of Technology, RPAS TEAM operating within the Center. The following methods were used during the research: literature analysis, inductive and deductive reasoning, unstructured interviews with airport experts and employees, experimental flights in the natural environment, simulations and measurements of analogue and digital signals.

Obtained results and measurement results can be used to implement UAV as an innovative element supporting the management of safety in order to better coordinate activities aimed at reducing or eliminating risks associated with air traffic at the airport and in the immediate vicinity.

\section{BSP as part of detection and monitoring systems}

The analysis of the scientific literature allows to conclude that available research results using the so-called drones are primarily focused on recognition and detection [4], planning collision avoidance pathways [12], detecting natural obstacles [7], identifying safe UAV landing zones [6], detecting errors [11], and not detecting other UAVs. Few works are devoted to the impact of unmanned technologies on improving emergency response within airports or airports [9]. Nevertheless, among the possible types of UAV applications at the airport can be distinguished:

- monitoring of the terrestrial traffic field, including runway status, taxiways and parking stands,

- monitoring, recording and deterring animals (birds and other wild animals),

- monitoring the technical condition of equipment and airport infrastructure,

- inspections of the technical condition of vehicles and aircraft,

- detection of other unmanned aerial vehicles,

- registration of the work of airport services,

- taking pictures, creating orthophotos,

- patrolling of roundabout zones, fences,

- detection and disposal of drones used for acts of unlawful interference (as a weapon of attack, including as a carrier of an explosive charge, chemical or biological weapon, missile).

\section{Research at the Katowice International Airport (EPKT)}

In the opinion of many representatives of airports and the aviation industry, using the drone as a tool for monitoring the airport is desirable. Viewing the area from height allows for proper assessment of the situation and can help in quick reaction, making the right decisions, minimizing the risk, better picture of the situation, detection of irregularities or defects.

In the case of detecting and neutralizing "hostile" drones, the "airport" UAV belonging to the airport manager and used by him may be a complement to the drone detection system, along with methods such as [1]: visible image analysis and infrared transmission from fixed cameras, noise measurement and frequency analysis characteristic for BSP, detection of specific radio signals including WiFi signal sources and RC equipment, FPV vision system or telemetry, passive active radars. During the research carried out by RPAS TEAM and Civil Aviation Cadastres Center in Central and Eastern Europe of the Silesian University of Technology, the unmanned aerial platform used has been very useful in monitoring around airfield areas and capturing a foreign drone with a net. So she could serve in the work of the Airport Security Guard.

As part of the tests at the Katowice International Airport (EPKT), an attempt was made to enter the flying object ("hostile" drone - hostile-UAV) above the runway 09 in 
Katowice. It should be noted that the enemy UAVs were detected before its start. The reason is that the detection system was based on the analysis of radio signals sent by RC devices (belonging to the "hostile" UAV operator) supported by infrared image analysis.

During the tests, the following problems were noted: (1) short range of radio signals, (2) long UAV airport arrival time to the "hostile" UAV. Noteworthy solutions are therefore increasing the range of radars (in the case of the first problem) and increasing the number of UAVs and their adapted landing sites/stands (in the case of the second problem). Increasing the number of airport UAVs patrolling the area of the airport and outside it will reduce the response time and increase the coverage of the monitored area. It also ensures the continuity of system operation in the event of failure of one of the UAV airports. The analysis of the location of the docking stations showed that the use of three unmanned platforms together with the prepared ground infrastructure is optimal (three landing and take off sites of UAV airports at various locations at the airport, ensuring battery replacement, quick service). This solution can shorten the reaction time in emergency situations. The operator of the UAV airport can pick up a device that is closest to the point requiring intervention.

Interestingly, the airport drone as a complement to the detection and monitoring system may prove to be useful in the light of the latest safety level tests in the opinion of air traffic controllers. Well, there is a lack of awareness among drone operators that flights performed in CTR can cause danger. The occasional lack of contact with operators (who turn off mobile phones for flights) makes it reasonable to monitor the vicinity of the airport and detect (and possibly neutralize) the "unintentionally" flying UAV.

The airport UAV can also serve the Airport Rescue and Fire Service (monitoring and recording accident locations), airport maintenance services, operation departments or infrastructure (monitoring and inspections of buildings, equipment, surfaces, roads, installations), operational departments or departments of duty departments (better illustration of the operational situation).

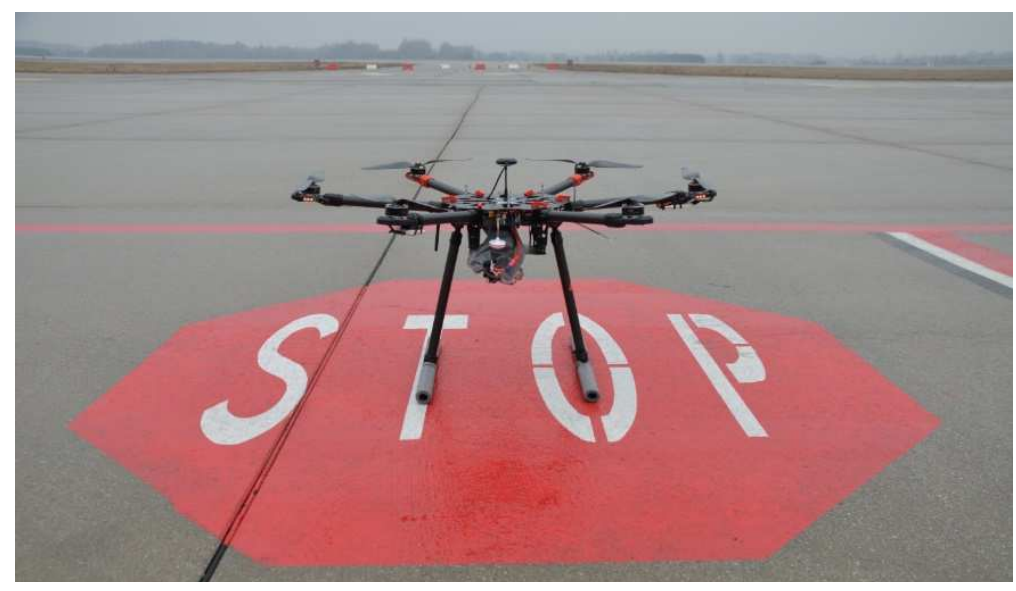

1. An unmanned aerial vehicle in Mezzia, the National Katowice Harbor in Pyrzowice Source: Adrian Łach. 


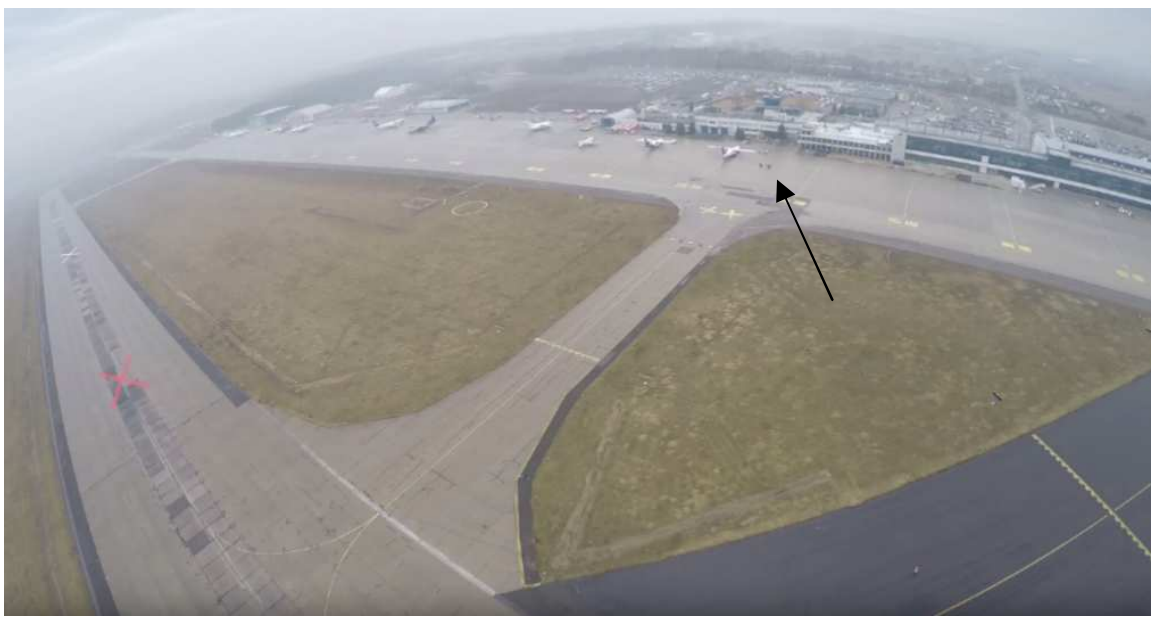

2. An image from an unmanned aircraft performing a flight over the airport. The arrow indicates the operator's position.

Source: Adrian Łach.

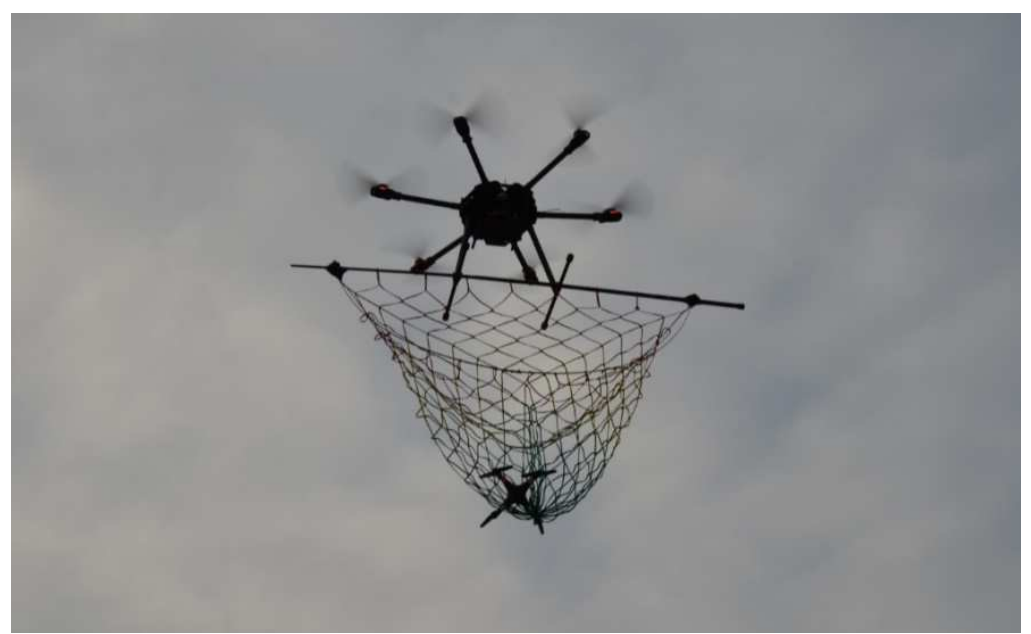

3. An attempt to catch a small drone

Source: Adrian Łach

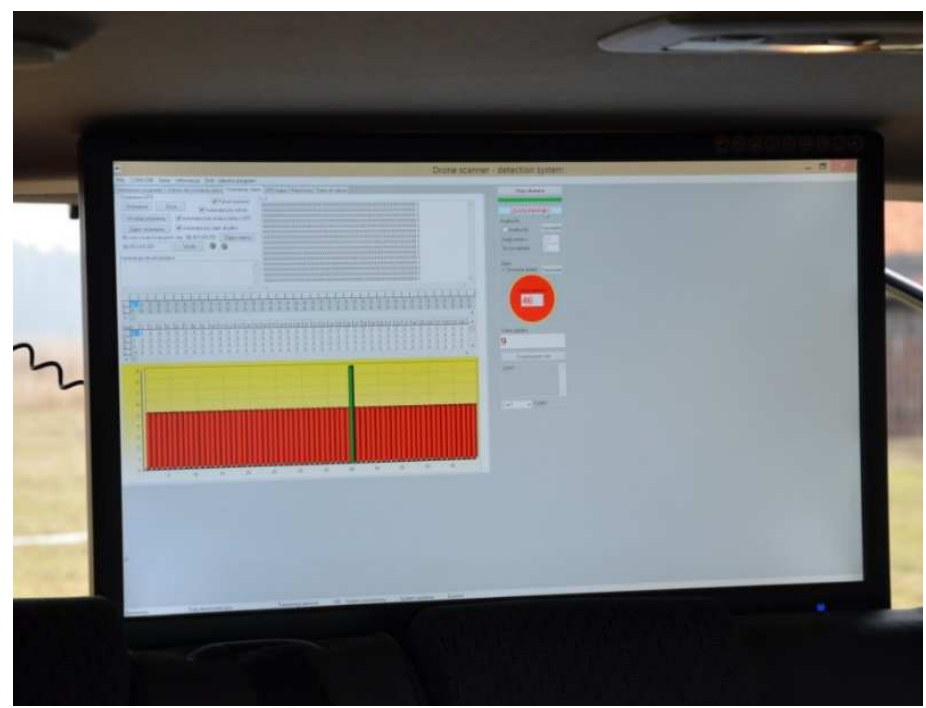

4. Testing of the UAV detection system installed in a mobile measuring station. The green bar means "hostile UAV.

Source: Adrian Łach 


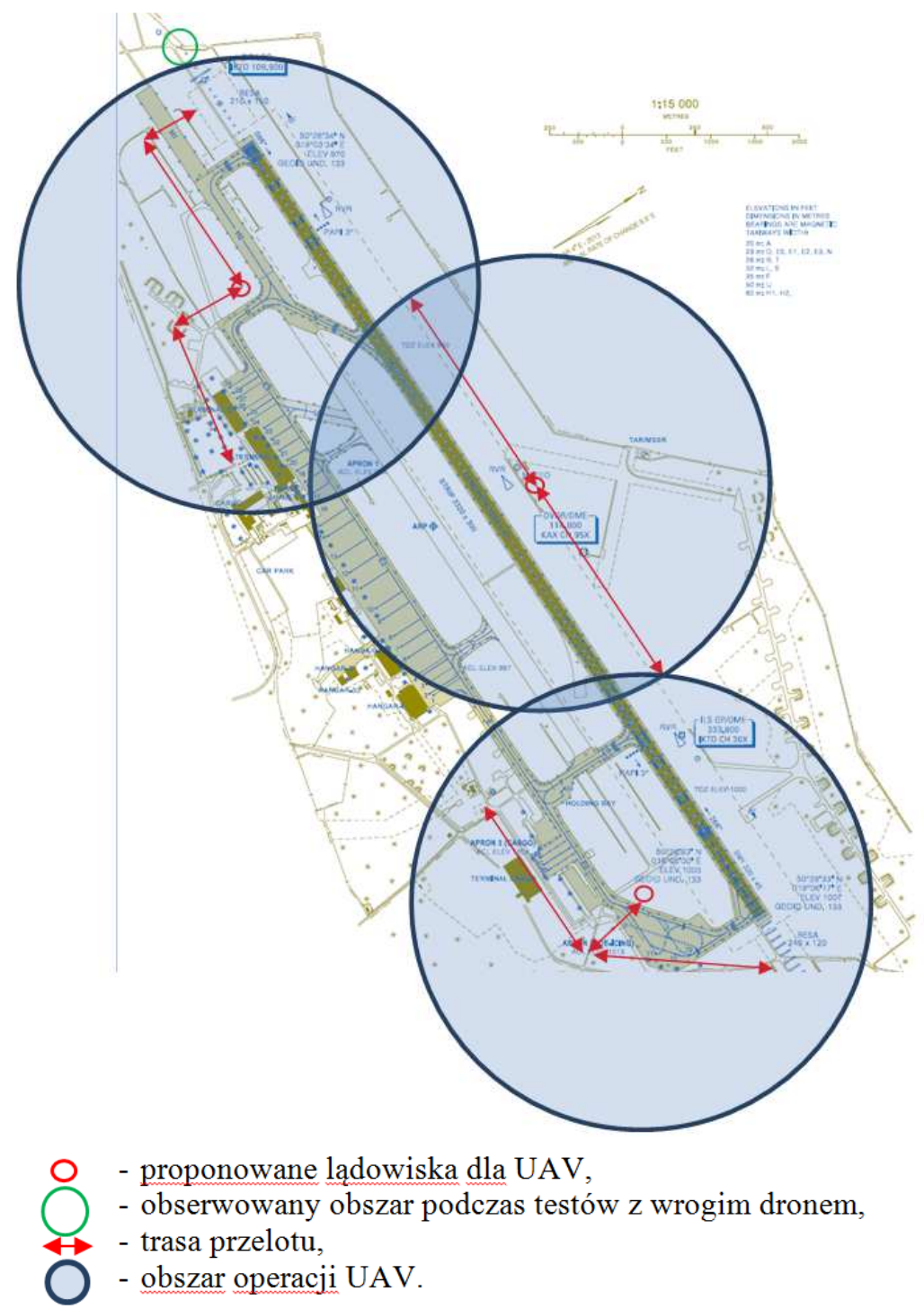

5. Map of operational activities and proposed landing sites for UAV Source: Adrian Łach 




6. View from the airport drone for parking spaces in EPKT

Source: archiwum własne autora.

\section{Summary}

In the era of threats from careless users of remotely controlled aircraft and terrorist attacks, it became necessary to ensure effective monitoring of near-center zones, detection of foreign drones and their disposal. The answer to this demand is the use of unmanned aerial vehicles by the airport manager. The studies, tests and analyzes undertaken have shown that:

- UAV can be a useful element of airport security management as an innovative tool for monitoring the technical condition of aircraft, equipment and airport infrastructure, patrolling fences, detection of other unmanned aerial vehicles and preventing collisions with birds,

- UAVs can improve the safety of takeoffs and landings by detecting potential threats,

- available drone detection systems are based on active and passive radars that detect radio signals emitted by the apparatus, controllers,

- what is important is the location of landing sites for BSPs belonging to airport services (at least three, although this also depends on the size of the airport and the zone that the operator wants to monitor),

- key parameters for the BSP of aerodrome services are: flight speed, camera resolution, takeoff speed (from the moment the equipment is switched on to BSP), resistance to adverse weather conditions,

- it is necessary to develop UAVO training programs tailored to the requirements and needs of airport services,

- providing image transmission from the airport UAV to units and services responsible at the airport for safety and security, e.g.: Airport Security Guard, Border Guard, Airport Rescue and Fire Service, departments of duty or operational service, police, Customs Service.

- it is necessary to integrate the airport UAV with the work of the crisis staff.

\section{Source materials}

[1] Fellner A., B. Mańka, A. Mańka, Analiza aktualnych metod detekcji bezzałogowych statków powietrznych (dronów), "TTS Technika Transportu Szynowego", 2015 R. 22 nr 12, s. 484-489.

[2] Mańka A., Łach A., Fellner R., UAV elementem zarządzania bezpieczeństwem portu lotniczego, „Wyzwania inżynierii ruchu lotniczego”, Warszawa 2016, s. 85-96. 
[3] Marzec D., Fellner R., „Latanie dronem w pobliżu portów lotniczych - w jaki sposób informuje się użytkowników o panujących zasadach?”, prezentacja podczas konferencji DroneTech 2nd World Meeting, Toruń, 6.10.2017 r.

[4] Merkisz, J. Nykaza, A., Zastosowanie bezzałogowych statków powietrznych w kryminalistyce rozpoznawczej i wykrywczej, "Autobusy : technika, eksploatacja, systemy transportowe", r. 17, nr 6, s. 297-301.

[5] Odpowiedź ULC z dn. 30.01.2017 r

[6] Patterson, T., McClean, S., Morrow, P., Parr, G., Luo, C. (2014). Timely autonomous identification of UAV safe landing zones, Image and Vision Computing, 32 (9), 568578.

[7] Rozporządzenie w sprawie przygotowania lotnisk do sytuacji zagrożenia oraz lotniskowych służb ratowniczo-gaśniczych, Dz.U. 2013 poz. 487.

[8] Savvaris, A., Melega, M., Tsourdos, A. (2015). Advanced Surface Movement and Obstacle Detection Using Thermal Camera for UAVs, IFAC-PapersOnLine, 48 (issue 9), 43-48.

[9] Terwilliger, B., Vincenzi, D., Ison, D., Witcher, K., Thirtyacre, D., Khalid, A. (2015). In-fluencing factors for use of unmanned aerial systems in support of aviation accident and emergency response, Journal of Automation and Control Engineering, 3 (3), 246.

[10] Ustawa z dnia 3 lipca 2002 r. Prawo lotnicze, Dz.U. 2002 nr 130 poz. 1112 z późn. zm., art. 68.

[11] Valavanis, K. P., Vachtsevanos, G. J. (2014). Handbook of Patterson, T., McClean, S., Morrow, P., Parr, G., Luo, C. (2014). Timely autonomous identification of UAV safe landing zones, Image and Vision Computing, 32 (9), 568-578.Unmanned Aerial Vehicles. Springer Publishing Company, Dordrecht, 1071-1181.

[12] www.fly4free.pl/na-lotniskach-system-do-niszczenia-dronow

[13] Zhu, L., Cheng, X., Yuan, F. G. (2016). A 3D collision avoidance strategy for UAV with physical constraints, Measurement, 77, 40-49 